5. Макарук Л. Л. Новітні лінгвістичні галузі дослідження невербальних усних та невербальних писемних засобів інтеракції. Наукові записки. Серія «Філологічні науки» Ніжин. держ. ун-ту ім. Миколи Гоголя / відп. ред. проф. Г. В. Самойленко. Ніжин : НДУ ім. М. Гоголя, 2016. Кн. 1. С. 181-185.

6. Infographics about Covid 19. Дата звернення: 09.02.2021. Режим доступу: https://www.google.com/search?q=infographics+about+covi d+19\&tbm=isch\&ved=2ahUKEwi0tY7Dru7vAhUM5IUKHYAIDpoQ2

DOI https://doi.org/10.30525/978-9934-26-110-7-35

\title{
TRANSFORMATIONS IN THE TRANSLATION OF BEOWULF FROM OLD ENGLISH TO PRESENT-DAY ENGLISH
}

\author{
Matkovska M. V. \\ Associate Professor at the English language department, \\ Kamyanets-Podilskiy Ivan Ohiyenko National University \\ Kamianets-Podilskyi, Khmelnytskyi region, Ukraine
}

The Old English epic poem Beowulf, composed between the middle of the $7^{\text {th }}$ and the end of the $10^{\text {th }}$ centuries, again and again, in the $20^{\text {th }}$ and the $21^{\text {st }}$ centuries attracts great interest of scholars and translators (such as Michael Alexander (1995), Robert Fulk (2010), Seamus Heaney (2000), R. M. Liuzza (2000), Oliver Raymond (1990), Purvis, (2012, 2021), M. Swanton (1997), J. Zupitza (2007), etc. Beowulf is a Scandinavian prince who saves the Danes from the seemingly invincible monster Grendel and, later, from Grendel's mother. Then he returns to his own country and dies in old age in a vivid struggle against a dragon. Beowulf is the elegiac narrative of the adventures of a Scandinavian hero who is constantly struggling for good and against evil.

Beowulf has been translated into Modern English many times. In general translators try to reproduce one or more of its remarkable features or qualities at the expense of others. The new verse translation by Seamus Heaney, while remaining reasonably faithful to the sense of the original, attempts to imitate its acoustic features - its rhythm, meter and alliteration - more closely than other translations (Heaney, 2000: 17). Some authors such as Meghan Purvis and Robert Fulk identify this phenomenon of translation by Heaney as «a creation of masterpiece out of a masterpiece» (Fulk, 2014: 29; Purvis, 2012: 141). Meghan Purvis favours the idea of Heaney to reflect «the somber grandeur and mythic vigor of the Anglo-Saxon original and the rhythm and 
timbre of the English language we speak today.... This newborn translation makes accessible to everyone the first supremely great poem to be written in the English language» (Purvis, 2012: 151).

In our research we will try to perceive the translational transformations, used by Seamus Heaney, such as alliteration, compounding, language change, formulas of breaking and language variation. It is recognized that like much early Germanic poetry, Old English did not use rhyme but alliteration.

Our aim is to identify the functional peculiarities of alliteration, language change and variation in the translation of the Old English text.

The text of Beowulf abounds in alliteration greatly - the use of the same consonant at the beginning of each word or each stressed syllable in a line of verse. For instance: Oft Scyld Scêfing sceapena ..., wēex under wolcnum, weorð-myndum pāh (Beowulf, 2000: 1); Scyldes eafera Scedelandum in. Swa sceal geong guma gode gewyrcean (Beowulf, 2000: 2); Heorogar ond Hroðgar ond Halga til; hyrde ic paet waes Onelan cwen, Heaðoscilfingas healsgebedda. pa waes Hroðgare heresped gyfen (Beowulf, 2000: 6); Hwanon ferigeað ge faette scyldas, grage syrcan ond grimhelmas, heresceafta heap (Beowulf, 2000: 22); Gēat waes glced-mōd, gēong sōna tō... (Beowulf, 2000: 122). Stressed syllables began with the same letter, which usually (but not always) represented the same phoneme; all consonants, however, were allowed to alliterate together. Like much early Germanic poetry, OE did not use rhyme but alliteration.

The Old English palatalized plosive consonants spelt $g, c g(3, \mathrm{c} 3) c, c c$ and the palatalized combination $s c$ developed in the course of the Old English period into sibilant sounds. This process was completed early in Middle English, and the digraphs $d g$, $c h$, sh were introduced for the new sibilant phonemes: e.g. [ $\int, \mathrm{t} \int$ and d3]. Scyld Scêfing (Shield Sheafson), sceal (shall), sceapena (scourage), scearde (cutting, shearing), cild (child), brycg (bridge), ecg (edge). On the other hand, the palatal plosives k' and g' disappeared from the English consonant system and it is clearly depicted in the translation of Seamus Heaney, e.g. geleorene (transitory), geap (wide, spread out), gewitan (know), gehrorene (fall down), geweorc (fortification), gebrēcon (break), gedreas (concourse).

In the new verse translation Heaney preserves alliteration as well, an example of Modern English alliterative verse: There was Shield Sheafson, scourge ... powers waxed ... his worth was proved (Beowulf, 2000: 2); Shield had fathered a famous son (Beowulf, 2000: 3); Heorogar, Hrothgar, the good Halga and a daughter, I have heard, who was Onela's queen, a balm in bed to be battle-scarred Swede (Beowulf, 2000: 7); Where do you come from, 
carrying these decorated shields and shirts of mail (Beowulf, 2000: 23); The Geat was elated and gladly obeyed (Beowulf, 2000: 123).

One more peculiar feature of language change in Anglo-Saxon variant of Beowulf is the maintenance of metathesis, Germanic gemination (doubling) and reflexes of common Germanic diphthongs in Old and Modern English. Seamus Heaney tries to preserve these types of language change with the aim of succession of the chronological development of the language (Heaney, 2000: 15).

Metathesis as a sound language change was of great structural importance, and it is worth mentioning because metathesis as something that persists throughout the history of the language; for example, the children's form wopse for PDE wasp (Fulk, 2014: 25-27). For example, ðridda - ðirda - third, brunnan - burnan - burn, hros - hors - horse, bresten - berstan - burst, cresse - cerse - cress, wcesp - wceps - wasp, wlisp - wlips - lisping, clēensian - clōesnian-cleanse, raen-cern-ran, etc.

The Old English poetry of Beowulf is characterized by a great number of compounding, the combining of two words to make a new word, e.g. wealstan - a compound word, made of weal (wall) and stan (stone) from Latin vallum. Examples of compounding in Beowulf are geār-dagum, literally «days gone by», Gar-Dena literally «Spear-Danes», gebrcecon - a word of the Germanic layer: Gothic brican, Old Saxon brekan, Old North breka with the literal meaning to break. Other examples of compounding may be as follows: burgstede - a compound word, made of burg (fortress) and stede (stead); from OHG burug-preserved in place-names ending in -bury (Canterbury); Lat. statio, stationis; the literal meaning - fortress, castle, town, place, spot, locality. Scurbeorge - a compound word, made of scur ('shower,' storm, tempest, trouble, commotion, breeze) and beorg(roof); Gothic skura, Old Saxon skur literally storm of battle, shower of blows. Eorðgrap - a compound word, made of eorð- (earth; ditch, furrow, drain and grap (grasp, grip, [grîpan] II. pret. 3 sg. of grîpan; Gothic airða, Old High German erda; literally to grasp the earth. Heardgripe- a compound word, made of heard (hard, harsh, stern, firm, brave; Gothic hardus, Old High German hart, Modern German hart and gripe (grasp, grip, [grîpan] II. pret. 3 sg. of grîpan; Gothic airða, Old High German erda; literally to grasp hard, to seize and hold firmly.

So, we may conclude that the most effective means of translating the Old English poem Beowulf into Modern English, used by Seamus Heaney are such as alliteration, compounding, derivation, conversion, language change and language variation in phonology and lexicon. To prove it, we may cite British and American scholars, concerning this translation. Meghan Purvis highly appreciates Heaney's alliterative translation that marches to an ancient beat 
that drives the poem forward. It's hard to miss Heaney's own flair, his grasp of language at once earthy and other worldly, his bold descriptions and his loud exclamation. Beowulf is exciting again (Purvis, 2021: 5). Robert Fulk recognizes the full worth of Heaney's excellent translation that has the virtue of being both direct and sophisticated, making previous versions slightly flowery and antique by comparison. His intelligence, fine ear and obvious love of the poem bring Beowulf alive as melancholy masterpiece, a complex Christian-pagan lament about duty, glory, loss and transience.... Heaney has done it (and us) a great service (Fulk, 2014: 28-29).

\title{
References:
}

1. Beowulf (2000). New York: Norton \& Company.

2. Fulk, Robert (2014. Beowulf and Language History. In The Dating of Beowulf: A Reassessment, ed. Leonard Neidorf. Cambridge: Boydell \& Brewer. Pp. 19-36.

3. Heaney, Seamus (2000). Beowulf. New York: Norton \& Company. Pp. 2-30.

4. Purvis, Meghan (2012). Towards a New Translation of Beowulf. UK, University of East Anglia.

5. Purvis, Meghan (2021). Beowulf. UK, University of East Anglia, Kindle Edition.

DOI https://doi.org/10.30525/978-9934-26-110-7-36

\section{КОГНІТИВНА СЕМАНТИКА У ПЕРСПЕКТИВІ КОНЦЕПТУАЛЬНОЇ СТРУКТУРИ ТА МОВНОГО ЗНАЧЕННЯ}

\author{
Мельничук О. Д. \\ кандидат філологічних наук, \\ доиент кафедри суспільно-гуманітарних дисииплін \\ Рівненська медична академія \\ м. Рівне, Україна
}

Вивчення когнітивної семантики розпочалося у 1970-х роках як реакція проти об'єктивістського погляду на світ, запропоноване англоамериканською традицією у філософії і суміжних галузях, наприклад, формальній лінгвістиці (truth-conditional semantics). Відтак у мовознавстві питання щодо зв'язку лексичного значення та концептуальної структури почали розглядати через призму когнітивного аналізу. Мета 